\title{
Human Rights Violations in Southeast Asia
}

\author{
The case of Khmer Rouge of 1975-1979 (Cambodia) and \\ The case of East Timor of 1999 (Indonesia)
}

\author{
Dr. Nazaruddin Nasution, MA \\ FISIP UIN JAKARTA
}

\begin{abstract}
This research proves that in the 40 years of ASEAN, none of the member countries free from human rights violations either ordinary or gross ones. ASEAN possesses instruments, namely the ASEAN Charter, the ASEAN Community, the National Commissions and AICHR to promote and protect human rights within ASEAN. One of human rights theories used in this paper is Francis Deng's Responsibility to Protect involving four categories of human rights violation (genocide, war crimes, ethnic cleansing, crimes against humanity), besides theory of natural rights, the universality of human rights and of Regionalism as well. This paper examines the case of genocide in Cambodia under the Khmer Rouge regime (1975-1979) and crimes against humanity in East Timor (1999), the resolution of both cases was resolved differently. Cambodia resolved it in judicial terms (the Khmer Rouge Tribunal), while Indonesia and Timor Leste overcame it in non-judicial terms (Commision of Truth and Friendship).
\end{abstract}

Keywords: Human rights, Responsibility to Protect, genosida, crimes against humanity

\section{INTRODUCTION}

This paper aims to prove that human rights violations have taken place in Southeast Asia. In the 50 years of ASEAN, none of the ASEAN member countries are free from the human rights violations, either the common or the specific ones. There are at least three reasons why human rights violations occur. First, the attitude of the rulers that allow violations of the law. Second, the different political treatment of groups within the community, and third, a social and economic gap in the society. The research also found the different ranking of ASEAN's human rights records based on the commitment of the member countries to some of the international human rights instruments. In the face of these human rights violations, ASEAN possesses four instruments and institutions, namely the ASEAN Charter, the ASEAN Community, the National Commission on Human Rights and the ASEAN Intergovernmental Commission on Human Rights (AICHR), which create efforts to promote and protect human rights within ASEAN. This paper uses three theories of human rights. The first is the John Locke's Theory of Natural Rights which affirms that human rights apply to every human being in society, either the minority (the ruler) or the majority (the people). Following that, the second theory is Dennis Driscoll's Universality of Human Rights that recognizes that human rights apply anywhere, anytime and for anyone. Last but not least, the third is Francis Deng's Responsibility to protect that underlines the state's responsibility to protect in the event of massive human rights violations involving four categories, namely genocide, war crimes, ethnic cleansing, and crimes against humanity. On the other hand, another theory called Theory of Regionalism has a different idea, it binds countries located in a particular area or region, in this case, Southeast Asia, to commit themselves to a broader society.

Furthermore, this paper examines precisely the case of law enforcement to solve human rights violations in two countries, namely genocide in Cambodia under the Khmer Rouge regime (1975-1979) and crimes against humanity in Indonesia (East Timor), shortly after the announcement of Act of Free Choice (1999). Both cases are in line with ASEAN's efforts to implement the ASEAN Charter in the principles of human rights, democracy, the rule of law and good governance as well as the ASEAN Community, consisting of three pillars: political-security, economic and socio-cultural pillars.

Table 1. The international protection of human rights: some key treaties, conventions, and declarations

\begin{tabular}{|c|l|}
\hline Year & \multicolumn{1}{|c|}{ Agreement } \\
\hline 1948 & $\begin{array}{l}\text { The Universal Declaration of Human Rights } \\
\text { (United Nations General Assembly) }\end{array}$ \\
\hline 1948 & $\begin{array}{l}\text { The Convention on the Prevention and } \\
\text { Punishment of the Crime of Genocide }\end{array}$ \\
\hline 1950 & $\begin{array}{l}\text { The European Convention for the Protection of } \\
\text { Human Right and Fundamental Freedoms }\end{array}$ \\
\hline 1965 & $\begin{array}{l}\text { The International Convention on the Elimination } \\
\text { of All Form of Racial Discrimination }\end{array}$ \\
\hline 1966 & $\begin{array}{l}\text { The International Covenant on Civil and Political } \\
\text { Rights and the International Covenant on } \\
\text { Economic, Social and Cultural Rights }\end{array}$ \\
\hline 1979 & $\begin{array}{l}\text { The American Convention on Human Rights } \\
\text { of Discrimination Against Women (CEDAW) }\end{array}$ \\
\hline 1981 & $\begin{array}{l}\text { The African Charter on Human and People's } \\
\text { Rights (the Bajul Charter) }\end{array}$ \\
\hline 1984 & $\begin{array}{l}\text { The Convention Against Torture and Other } \\
\text { Cruel, Inhuman or Degrading Treatment or } \\
\text { Punishment }\end{array}$ \\
\hline 1984 & \begin{tabular}{l} 
The Convention on the Rights of the Child \\
\hline 1989
\end{tabular} \begin{tabular}{l} 
The Declaration of Principles of Indigenous \\
Rights \\
\hline 1993
\end{tabular} \begin{tabular}{l} 
The Vienna Declarations and Action Programme \\
\hline Source: The Globalization of World Politics 4e, p. 508
\end{tabular} \\
\hline 19
\end{tabular}




\section{THREE FACTORS THAT TRIGGER HUMAN RIGHTS VIOLATION IN SOUTH EAST ASIA}

There are three main factors that trigger human rights violations in Southeast Asia. The first one is the acts of violence perpetrated by the ruling classes against community groups (vertical conflict). Second, the conflict also occurs due to the ongoing conflict between community groups in a country, which escalates and ends with social clashes (horizontal conflict). The last cause is the condition when individuals undertook specific behavior and actions against other individuals due to disputes motivated by political, economic, social or cultural factors. One of the most prominent causes of human rights abuses, including massive human rights violations, is the unreasonable acts perpetrated by the ruler of a state by the force that is imbued with the religious matter. For example, the non-Muslim rulers in several states in Southeast Asia that act against Muslim minorities, such as Rohingya in Myanmar, Pattani in Thailand and Moro in the Philippines.

A similar situation also occurs in the Communist countries, where the majority group goes against the non-Communist minority group. Such a condition happened in Vietnam, Laos, and Cambodia. Human rights violations can also occur when the Muslim majority rulers in the countries like Malaysia, Indonesia and Brunei perform negligence of law enforcement. These are, among other things, experienced by the Christian, Hindu, Buddhist or Ahmadiyah and Shiite groups in Indonesia.

According to Mahdev Mohani, in addition to communist systems that are still embraced by Vietnam and Laos, ASEAN countries can be classified into two categories of power systems. First is the authoritarian or limited democracy that is implemented in Myanmar, Malaysia, Singapore and Brunei Darussalam. The second system is the constitutionalism or transitional justice, which can be found Cambodia, Philippines, Thailand, and Indonesia.

ASEAN's member states can also be classified based on the scale of human right violations cases that happen in the country. There are countries with smaller-scale human rights violations such as Singapore, Malaysia, Brunei, Vietnam, and Laos. There also countries that have massive human rights violation cases namely Myanmar, Thailand, the Philippines, Indonesia, and Cambodia.
Table 2. Status of Human Rights Protection

\begin{tabular}{|c|c|c|c|c|}
\hline Country & $\begin{array}{l}\text { Freed } \\
\text { om } \\
\text { Ranki } \\
\text { ng* }\end{array}$ & $\begin{array}{c}\text { Human } \\
\text { Developm } \\
\text { ent } \\
\text { Index** }\end{array}$ & $\begin{array}{c}\text { Press } \\
\text { Freedom } \\
\text { Ranking } \\
* * *\end{array}$ & $\begin{array}{c}\text { Human } \\
\text { Rights } \\
\text { Ratificatio } \\
\text { ns }\end{array}$ \\
\hline Brunei & $\begin{array}{l}\text { Not } \\
\text { Free }\end{array}$ & Very High & Difficult & $3 / 22$ \\
\hline Cambodia & $\begin{array}{l}\text { Not } \\
\text { Free }\end{array}$ & Medium & Difficult & $11 / 22$ \\
\hline $\begin{array}{l}\text { Timor } \\
\text { Leste }\end{array}$ & $\begin{array}{l}\text { Partly } \\
\text { Free }\end{array}$ & Medium & $\begin{array}{l}\text { Satisfacto } \\
\text { ry }\end{array}$ & $11 / 22$ \\
\hline Indonesia & $\begin{array}{l}\text { Partly } \\
\text { Free }\end{array}$ & Medium & Difficult & $11 / 22$ \\
\hline Laos & $\begin{array}{l}\text { Not } \\
\text { Free }\end{array}$ & Medium & $\begin{array}{c}\text { Very } \\
\text { Serious }\end{array}$ & $9 / 22$ \\
\hline Malaysia & $\begin{array}{l}\text { Partly } \\
\text { Free }\end{array}$ & High & Difficult & $5 / 22$ \\
\hline Myanmar & $\begin{array}{l}\text { Not } \\
\text { Free }\end{array}$ & Low & Difficult & $4 / 22$ \\
\hline $\begin{array}{c}\text { Philippine } \\
\text { S }\end{array}$ & $\begin{array}{l}\text { Partly } \\
\text { Free }\end{array}$ & Medium & Difficult & $14 / 22$ \\
\hline Singapore & $\begin{array}{l}\text { Partly } \\
\text { Free }\end{array}$ & Very High & Difficult & $3 / 22$ \\
\hline Thailand & $\begin{array}{l}\text { Partly } \\
\text { Free }\end{array}$ & High & Difficult & $11 / 22$ \\
\hline Vietnam & $\begin{array}{l}\text { Not } \\
\text { Free }\end{array}$ & Medium & $\begin{array}{c}\text { Very } \\
\text { Serious }\end{array}$ & $7 / 22$ \\
\hline
\end{tabular}

*FreedomHouse's 2014 ranking of Freedom in the World. Three ranking are awarded: Free, Partly Free or Not Free

** From the UNDP's 2014 Human Development Index, States can have very high, high, medium or low human development

*** From Reporters Without Borders'2014 World Press Freedom Index. The situation can be good, satisfactory, noticeable problems, difficult, or very serious

The Vienna Conference on Human Rights, held in Vienna in 1993, provide the international stage which discussed the cultural, philosophical, academic, and political debate on "Asian exceptionalism." There were 171 participating countries and more than 800 non-governmental organizations (NGOs) involved in this conference. It results in the Vienna Declaration and Program of Actions, which is are considered as the starting point of a new era of human rights implementation [1]. 


\section{Cases of violation of human rights within ASEAN}

One of the human rights violations in ASEAN is the Rohingya case. The latest development of that crisis opened the possibility for one ASEAN member country, in this case, Indonesia, to play the role bilaterally in trying to solve the problem faced by the Rohingya people. It indicated that Myanmar has a good intention to address parts of the problem that is related to the humanitarian assistance. However, the political and legal aspects of this case remain unsolved. The country has not addressed the issues related to the Responsibility to Protect concept, and the recognition for the Rohingyas to be accepted ast part of the Myanmar people.

The existence of the non-interference principle makes the issue becomes more difficult to solve. The ASEAN Intergovernmental Commission on Human Rights (AICHR) asan institution that is expected to resolve the problem is unable to do much because of its inadequate authority. From the viewpoint of ASEAN, it is difficult to reach a consensus in this humanitarian conflict due to the two different and contradicting views between Myanmar and other ASEAN members [4].

\section{The case of Khmer Rouge of 1975-1979 (Cambodia)}

The substantial experiments in international criminal justice have been taking place at the Extraordinary Chambers in the Courts of Cambodia (ECCC), a tribunal created by the United Nations and Cambodian Government to adjudicate some of the most egregious crimes of the Pol Pot era [2]. Between April 17, 1977, and January 6, 1979, the Khmer Rouge systematically murdered at least 1.7 million peoplejust over 20 percent of the population of Cambodia. In 2006, the ECCC came into operation, with the hopes of many Cambodians, and, indeed, members of the international community that those responsible for one of the worst humanitarian atrocities of the twentieth century would finally be held to account for their actions. ECCC has much in common with other hybrid tribunals which share certain disadvantages such as the challenge of mixing local and foreign practices and personnel, as well as the involvement of a host government with a weak judicial capacity. The first case that came to the public before the ECCC was the case of Kaing Guek Eav, or known as Comrade Duch, the Chairman of Toul Sleng Prison. It is estimated that 17,000 individuals were imprisoned and killed [3]. He is currently serving a life prison sentence. The second case had four defendants: Nuon Chea (87), known as "Brother Number 2" and Khieu Samphan (82), who was the former head of state. Both of them also got a life prison sentence. However, Khmer Rouge foreign minister Ieng Sery died in 2013, and his wife, Ieng Thirit, another senior regime figure, was declared mentally ill, hence unable to stand trial in 2011 [6].

\section{The case of East Timor of 1999 (Indonesia)}

On 21 December 2004, Indonesia and Timor-Leste declared they would jointly establish a Commission of Truth and Friendship (CTF) to investigate the 1999 violence, which resulted in around 2000 victims [5]. The aim of the Commission of Truth and Friendship (CTF), built in May 2005, was to establish the truth about human rights violations before and after the referendum in 1999. Besides that, it also aimed to prepare recommendations to "healing the wounds of the past and strengthening friendship" between the two nations (CTF 2008, i). Leigh-Ashley Lipscomb, who assisted in producing the expert advisors reports to the CTF, suggests that Timor-Leste cited "geopolitical vulnerability" as a justification for inaction on past crimes. As a fragile state, Timor-Leste's leadership recognizes it does not have the political power to compel Indonesia to alter its policies, and any attempts to apply pressure, which are likely to undermine Timor-Leste's national security and economic interests [5].

Table 3. Comparison between the solution to the case of gross violation of human rights in Cambodia and East Timor, Indonesia

\begin{tabular}{|c|c|}
\hline Khmer Rouge, Cambodia & East Timor, Indonesia \\
\hline $\begin{array}{l}\text { 1. The existence of } \\
\text { "political will" from the } \\
\text { Cambodian government } \\
\text { and the United Nations } \\
\text { (international } \\
\text { instrument) }\end{array}$ & $\begin{array}{l}\text { 1. The existence of } \\
\text { "political will" from } \\
\text { the Indonesian and } \\
\text { Timor Leste } \\
\text { governments (bilateral } \\
\text { instrument) }\end{array}$ \\
\hline $\begin{array}{l}\text { 2. There are "pressures" } \\
\text { from outside power } \\
\text { (external) }\end{array}$ & $\begin{array}{l}\text { 2. There are "pressures" } \\
\text { from inside and } \\
\text { outside (external) } \\
\text { power }\end{array}$ \\
\hline $\begin{array}{l}\text { 3. The process is in the } \\
\text { form of "judicial" (the } \\
\text { establishment of Khmer } \\
\text { Rouge Tribunal, agreed } \\
\text { upon by the Cambodian } \\
\text { government and the } \\
\text { United Nations) }\end{array}$ & $\begin{array}{l}\text { 3. The process is in the } \\
\text { form of "non-judicial" } \\
\text { (the establishment of } \\
\text { the Commission of } \\
\text { Truth and Friendship, } \\
\text { agreed upon by the } \\
\text { government of } \\
\text { Indonesia and the } \\
\text { government of Timor } \\
\text { Leste) }\end{array}$ \\
\hline 4. No Remedy & 4. No Remedy \\
\hline 5. Non Recurrence & 5. Non Recurrence \\
\hline
\end{tabular}

Indonesia's contribution to the settlement of the Cambodian case (1970-1991) has given a blue report card to Indonesia with its role as an interlocutor and a peace-maker. Meanwhile, Indonesia's involvement in the East Timor case (1975-1999), particularly before and right after Act of Free Choice in 1999, is considered as a crime against humanity, which has resulted in Indonesia obtaining a red report card by the international community. 


\section{References}

[1] Attilio Pisano. Human Rights and Sovereignty in the SEN Path Towards a Human Rights Declaration in Hum Rights Rev (2014) 15:391-411.

[2] John D. Ciorciari and Anne Heindel. Experiments in International Criminal Justice: Lessons from the Khmer Rouge Tribunal in Michigan Journal of International Law, (Vol. 35:370 Winter 2014)

[3] Renee Jeffery. The forgiveness dilemma: emotions and justice at the Khmer Rouge tribunal in Australian Journal of International Affairs, 2015, Vol. 69, No.1.

[4] Riski Muhamad Baskoro . Examining ASEAN Charter of Human Rights: Study Case of Rohingya Crisis. International Journal of Humanities and Applied Sciences (IJHAS) Vol. 5, No. 2, 2016 ISSN 2277 - 4386

[5] Strating, Rebecca. The Indonesia-Timor Leste Commission of Truth and Friendship: Enhancing Bilateral Relations at the Expence of Justice in Contemporary South East Asia, Vol. 36, No. 2 (2014).

[6] http://htttime.com/6997/cambodias-khmer-rouge-trialsare-a-shocking-failure/ 